\title{
Cutaneous Melanoma Pathologic Distant Metastasis TNM Finding v7
}

National Cancer Institute

\section{Source}

National Cancer Institute. Cutaneous Melanoma Pathologic Distant Metastasis TNM

Finding v7. NCl Thesaurus. Code C88394.

A pathologic finding about one or more characteristics of cutaneous melanoma,

following the rules of the TNM AJCC V7 classification system as they pertain to distant

metastases. There is no pathologic M0 for cutaneous melanoma. (from AJCC 7th Ed.) 